\title{
Effects of Mg-modified Biochar on the Bioavailability of Cadmium in Soil
}

\author{
Ruifeng Shan, a,b,* Wanting Li, ${ }^{\text {a,b }}$ Ya Chen, ${ }^{\mathrm{a}, \mathrm{b}}$ and Xiaoyin Sun ${ }^{\mathrm{a}, \mathrm{b}}$ \\ The remediation effects of peanut shell biochar (HBC) and Mg-modified \\ peanut shell biochar (MHBC) prepared under pyrolysis temperatures of \\ $300{ }^{\circ} \mathrm{C}$ and $600{ }^{\circ} \mathrm{C}$ on $\mathrm{Cd}^{2+}$ polluted brown soil were investigated in a pot \\ experiment. The results showed that the biochar treatment increased soil \\ $\mathrm{pH}$ and decreased the bioavailable $\mathrm{Cd}^{2+}$ content in the soil. Compared with \\ the control treatment $(\mathrm{CK})$, the $\mathrm{pH}$ value increased by 0.32 to 2.5 upon \\ treatment with $1 \%$ and $2 \%$ of $\mathrm{HBC}$ and MHBC. Bioavailable $\mathrm{Cd}^{2+}$ in the \\ soil decreased by $5.64 \%$ to $21.33 \%$ with HBC. The MHBC presented \\ better amendment effects than HBC; bioavailable $\mathrm{Cd}^{2+}$ in the soil \\ decreased by $26.2 \%$ to $50.1 \%$ with the addition of MHBC. The addition of \\ $\mathrm{HBC}$ and MHBC increased the shoot height and decreased the root length \\ of the spinach. Moreover, they significantly decreased the accumulation of \\ $\mathrm{Cd}^{2+}$ in the shoots and roots of the spinach. Compared to $\mathrm{CK}$, the $\mathrm{Cd}^{2+}$ \\ content in the shoots decreased by $7.0 \%$ to $46.8 \%$ upon treatment with \\ $1 \%$ and $2 \%$ of $\mathrm{HBC}$ and $\mathrm{MHBC}$, while the $\mathrm{Cd}^{2+}$ content in the roots \\ decreased by $7.3 \%$ to $52.7 \%$. The $\mathrm{Cd}^{2+}$ content in the shoots and roots \\ was more greatly decreased with MHBC than with HBC.
}

Keywords: Magnesium-modified biochar; Cadmium; Remediation; Spinach; Bioavailability

Contact information: a: Key Laboratory of Nansihu Lake Wetland Ecological Conservation \& Environmental Protection (Shandong Province), College of Geography and Tourism, Qufu Normal University, Rizhao 276826, People's Republic of China; b: Rizhao Key Laboratory of Territory Spatial Planning and Ecological Construction, Rizhao 276826, People's Republic of China;

*Corresponding author: ruifengshan@ sina.com

\section{INTRODUCTION}

Cadmium $(\mathrm{Cd})$ is widely used in electroplating and metallurgy. The toxicity of $\mathrm{Cd}$ causes major environmental problems in soils worldwide. Soils are the largest source and sink of Cd. In China, according to the National Soil Pollution Survey, the standard pollution rate of $\mathrm{Cd}$ in 4,095 typical sampling sites was 7\% greater than those of other heavy metals (Wang et al. 2015). Research shows that Cd can cause stress to plant growth, resulting in reduced plant biomass even at trace concentrations (Dai et al. 2020). Cadmium(II) induces plant cells to produce excessive reactive oxygen species, generating oxidation products such as hydrogen peroxide and peroxide ions. These species affect the redox balance in the plants and damage the integrity of plant cell membranes to varying degrees (Laspina et al. 2005; Guo et al. 2019; Sidhu et al. 2020). The bioavailability of heavy metals is closely related to the extent of damage to plants and animals. Heavy metals with high bioavailability are more likely to be absorbed by plants. Vegetables, fruits, and crops planted in heavy-metal-contaminated soils or irrigated with sewage containing a high content of heavy metals pose potential threats to human health (Farrag et al. 2012). Therefore, technologies to control the bioavailability of soil $\mathrm{Cd}$ should be studied. Present amendment technologies for $\mathrm{Cd}$ removal include physical remediation, chemical 
remediation, and bioremediation. Soil amendments can decrease the bioavailability of heavy metals through adsorption, complexation, and other mechanisms to fix heavy metals and decrease uptake by animals and plants. Soil amendment is an economical, efficient, and environmentally friendly remediation method (Ashrafi et al. 2015; Bashir et al. 2020), but the results of different soil amendments vary greatly (Zhang et al. 2020). At present, the addition of biochar to soil is one of the most promising soil remediation methods.

Biochars are porous carbonaceous materials with high specific surface area, and they are produced by the pyrolysis of organic matter under high temperature $\left(>300^{\circ} \mathrm{C}\right)$ in anoxic or anaerobic environments (Sun et al. 2017; Cairns et al. 2020; Shan et al. 2020). The addition of biochar can improve soil quality, thereby promoting plant growth. Moreover, biochar has a well-developed pore structure, high specific surface area, and abundant surface functional groups (Sun et al. 2017; Chen et al. 2020). Therefore, biochar is an efficient and low-cost adsorbent that can effectively adsorb inorganic and organic pollutants, thereby decreasing their concentrations and bioavailabilities (Jin et al. 2016; Awad et al. 2020). Ali et al. (2020) used apricot shell and apple tree biochars to transform $\mathrm{Cd}$ and $\mathrm{Zn}$ from acid-soluble and reducible forms to organic-bound and residue fractions, which are less bioavailable. Consequently, their accumulation in the roots and shoots of mustard were decreased. In recent years, biochar has been widely used for the remediation of soil pollution. However, the remediation efficiency of a single type of pristine biochar for the removal of organic and inorganic pollutants in soil is limited (Fan et al. 2018). Therefore, researchers have combined biochar with other substances such as iron oxides (Micháleková-Richveisová et al. 2017), copper oxide (Li et al. 2020b), calcium carbonate (Wu et al. 2020), and graphene oxide (Shang et al. 2016) to remediate soils contaminated by heavy metals. Moreover, heavy metal fixation by biochar in soils is influenced by the pyrolysis temperature, concentration, and physicochemical properties of the biochar. Wang et al. (2020) observed that the content of Cd accumulated in maize decreased upon the addition of biochar prepared at $300{ }^{\circ} \mathrm{C}$ compared to that prepared at $700{ }^{\circ} \mathrm{C}$. In another study, as the concentration of bamboo and rice stalk biochars increased from $0 \%$ to $5 \%$, the concentration of $\mathrm{CaCl}_{2}$-extractable $\mathrm{Cd}$ in the soil gradually decreased (Yang et al. 2016). Awad et al. (2020) suggested that the contents of heavy metal in the soil and plant issues decreased after adding garden waste biochar and the reduction was higher in $6 \%$ of the biochar treatment than $4 \%$. According to the aforementioned studies, the concentration and pyrolysis temperature of the biochar can affect the fraction of heavy metals in the soil, but the mechanisms of the reactions are not clear. Therefore, a new modified biochar should be developed to improve the remediation efficiency of biochar, and its pyrolysis temperature, concentration, mechanisms, and influencing factors should be investigated.

Spinach is one of the most popular vegetables in China. High concentration of $\mathrm{Cd}$ can accumulate in edible parts of leafy vegetables, such as spinach and lettuce. The human consumption of such a vegetable which contains a great amount of heavy metal presents a potential risk for human health (Huang et al. 2017). Magnesium ion is an essential element for its growth which can lead to exchange of heavy metal ions in the soil, thereby improving the adsorption efficiency of the biochar. Tao's team found that the sorption capacity of the Thalia dealbata biochar for $\mathrm{Cd}$ in sediment was improved by 24.2 to $25.6 \%$ after loading $\mathrm{MgCl}_{2}$ (Tao et al. 2019). Li et al. (2020) suggested that the maximum theoretical saturation adsorption amount of $\mathrm{Mg}$-modified biochar for $\mathrm{Cd}$ in wastewater was up to $370 \mathrm{mg} / \mathrm{g}$. These research studies about $\mathrm{Mg}$-modified biochar mainly focused on its sorption behavior in two different environmental matrixes. However, the influence of Mg-modified biochar on the bioavailability of $\mathrm{Cd}$ in soil and the effect on plant growth status have not been well 
understood. Further efforts are necessary to evaluate the effect of the Mg-modified biochar on $\mathrm{Cd}$ in soil from the aspect of bioavailability. Therefore, this study attempts to prepare $\mathrm{Mg}$-modified biochar and explore its optimum concentration and pyrolysis temperature to reduce the bioavailability of $\mathrm{Cd}$. Peanut shell biochar (HBC) and $\mathrm{Mg}$-modified peanut shell biochar (MHBC) were prepared via $300{ }^{\circ} \mathrm{C}$ and $600{ }^{\circ} \mathrm{C}$ pyrolysis and added to soil samples at $1 \%$ and $2 \%$ concentrations. The growth and $\mathrm{Cd}$ content of spinach were used to evaluate the passivation effect of $\mathrm{Cd}$ by $\mathrm{HBC}$ and $\mathrm{MHBC}$ at different concentrations and pyrolysis temperatures.

\section{EXPERIMENTAL}

\section{Preparation and Treatment of Soil Samples}

Brown surface soil $(0 \mathrm{~cm}$ to $20 \mathrm{~cm})$ samples were collected from Rizhao, Shandong Province, China. The soil samples were dried, ground, and sieved through 2-mm, 1-mm, and $0.15-\mathrm{mm}$ sieves to prepare for the pot experiment, $\mathrm{pH}$ detection, and analysis of total organic matter and heavy metal content, respectively. The basic physicochemical properties of the soil samples are shown in Table 1.

Table 1. Basic Physicochemical Properties of Soil Samples

\begin{tabular}{|c|c|c|c|c|}
\hline Type of Soil & $\mathrm{pH}$ & $\begin{array}{c}\text { Organic Matter } \\
\text { Content } \\
(\mathrm{g} / \mathrm{kg})\end{array}$ & $\begin{array}{c}\text { Total N } \\
(\%)\end{array}$ & $\begin{array}{c}\text { Total P } \\
(\%)\end{array}$ \\
\hline Brown soil & 6.17 & 2.4 & 0.057 & 0.063 \\
\hline
\end{tabular}

\section{Preparation and Characterization of Biochar}

The pristine biochar was prepared from peanut shells. Peanut shells were first washed three times with deionized water, and they were then dried to a constant weight at $50{ }^{\circ} \mathrm{C}$ before being ground into powder. The biochar was produced from the obtained powder by placing it in a porcelain crucible with a cap and pyrolyzing it in a muffle furnace for $2 \mathrm{~h}$ at $300{ }^{\circ} \mathrm{C}(300 \mathrm{HBC})$ and $600{ }^{\circ} \mathrm{C}(600 \mathrm{HBC})$ under an oxygen-limited $\mathrm{N}_{2}$ atmosphere. The $\mathrm{N}_{2}$ gas was inserted at $10 \mathrm{~L} / \mathrm{min}$, and the heating rate was approximately $15^{\circ} \mathrm{C} / \mathrm{min}$. The samples were then ground and sieved through a $0.6-\mathrm{mm}$ sieve after the temperature decreased to room temperature.

To prepare the Mg-modified peanut biochar, peanut shells were first soaked in an $\mathrm{MgCl}_{2}$ solution (at a solid-liquid ratio of 1:10 w/v) in an ultrasonic oscillator for $6 \mathrm{~h}$ (Tao et al. 2019). They were then cleaned with deionized water, placed in a crucible, and dried at $105{ }^{\circ} \mathrm{C}$ before being ground into powder. The pyrolysis process was the same as mentioned above, and the samples were labeled as "300MHBC" and "600MHBC." The characterization of the biochar is described in Chen et al. (2020).

\section{Experimental Methods}

The bioavailability of $\mathrm{Cd}$ in the biochar-amended soil was investigated through experiments. The soil treatments were the control treatment $(\mathrm{CK}), 1 \% 300 \mathrm{HBC}$, $2 \% 300 \mathrm{HBC}, 1 \% 600 \mathrm{HBC}, 2 \% 600 \mathrm{HBC}, 1 \% 300 \mathrm{MHBC}, 2 \% 300 \mathrm{MHBC}, 1 \% 600 \mathrm{MHBC}$, and $2 \% 600 \mathrm{MHBC}$. The percentages refer to the mass ratio in the soil (i.e., biochar concentration), 300 and 600 indicate the corresponding pyrolysis temperature $\left({ }^{\circ} \mathrm{C}\right), \mathrm{HBC}$ refers to pristine biochar, and $\mathrm{MHBC}$ refers to $\mathrm{Mg}$-modified biochar. 
A stock solution of $1000 \mathrm{mg} / \mathrm{L} \mathrm{Cd}\left(\mathrm{NO}_{3}\right)_{2} \cdot 4 \mathrm{H}_{2} \mathrm{O}$ was added to the soil and mixed evenly. A soil sample with a Cd content of $10 \mathrm{mg} / \mathrm{kg}$ was prepared and air dried, followed by homogenization. The polluted soil was added to the plastic pots, and the moisture content of the soil was maintained at $60 \%$ of the water holding capacity. After 2 weeks, 1 $\mathrm{g}$ of urea was added as base fertilizer and mixed evenly. The pristine biochar and $\mathrm{Mg}$ modified biochar $(300 \mathrm{HBC}, 600 \mathrm{HBC}, 300 \mathrm{MHBC}, 600 \mathrm{MHBC})$ were then mixed with the soil at $0 \%, 1 \%$, and $2 \%$ mass fractions. The moisture contents of the soil samples were maintained at $65 \%$ of water holding capacity by adding distilled water, and the soil was cultured alternately under moist and dry conditions in a greenhouse for 1 week. All experiments were conducted in triplicate, and the average values were used for the analysis. A total of 27 treatments were established and performed.

Spinach was selected as the indicator of Cd bioavailability in the soil. The spinach seeds were disinfected by soaking in $6 \% \mathrm{NaClO}$ solution for $20 \mathrm{~min}$. Then, the seeds were removed and rinsed with tap water three times, followed by washing with distilled water. Three seeds were planted in each plastic pot filled with $500 \mathrm{~g}$ of soil. The plastic pots were placed in an artificial greenhouse, and their positions were randomly changed every two weeks. The spinach samples were harvested after five weeks of cultivation.

\section{Soil Sampling and Analysis}

Soil samples were collected and then air-dried on the $30^{\text {th }}$ day after the spinach was planted in the plastic pots. The soil $\mathrm{pH}$ was measured by a $\mathrm{pH}$ meter. For that, $5.0 \mathrm{~g}$ of soil sample was weighed and sieved $(1 \mathrm{~mm})$. The soil sample was placed in a 50-mL centrifuge tube, and $25 \mathrm{~mL}$ of deionized water was added to it for a soil:water ratio of 1:5 (w/v). The centrifuge tubes were oscillated at $180 \mathrm{rpm}$ for $30 \mathrm{~min}$, then centrifuged at $4000 \mathrm{rpm}$ for 10 min. Finally, the $\mathrm{pH}$ of the supernatant was measured with the $\mathrm{pH}$ meter.

Next, soil samples of $5.0 \mathrm{~g}$ were screened by a $0.15-\mathrm{mm}$ sieve, then weighed in a $50-\mathrm{mL}$ centrifuge tube. Subsequently, a $0.1 \mathrm{~mol} / \mathrm{L} \mathrm{CaCl}_{2}$ solution $(1: 25$ soil:water ratio) was added to the tube and oscillated for $2 \mathrm{~h}$ at $180 \mathrm{rpm}$ and $25^{\circ} \mathrm{C} \pm 1{ }^{\circ} \mathrm{C}$. The samples were then centrifuged at $4000 \mathrm{rpm}$ for $10 \mathrm{~min}$ and filtered through a $0.22-\mu \mathrm{m}$ membrane. The supernatant was collected to determine the concentration of bioavailable $\mathrm{Cd}^{2+}$.

A soil sample of $0.2 \mathrm{~g}$ was moistened with distilled water and placed in a crucible, and $10 \mathrm{~mL}$ of $\mathrm{HCl}$ was added to it. The sample was heated at $80{ }^{\circ} \mathrm{C}$ for evaporation until the solution in the crucible was approximately $3 \mathrm{~mL}$. A mixture solution of $\mathrm{HNO}_{3}, \mathrm{HF}$, and $\mathrm{HClO}_{4}(5: 5: 3 \mathrm{v} / \mathrm{v} / \mathrm{v})$ was added and heated at $180{ }^{\circ} \mathrm{C}$ for $1 \mathrm{~h}$ with a lid. Afterwards, the lid was opened to remove silicon and then closed to decompose the black organic carbide when the thick white perchloric acid smoke emerged. Before the lid was opened to remove the white smoke, the black organic matter on the crucible wall was already absent. The crucible was cooled to room temperature, and $1 \mathrm{~mL}$ of $\mathrm{HNO}_{3}$ solution was added. The mixture was transferred into a 25-mL colorimetric tube, mixed evenly, and left to stand overnight. The results of atomic absorption testing (see later) determined the total $\mathrm{Cd}$ in the soil.

\section{Plant Sampling and Analysis}

After 5 weeks of culturing, three spinach samples were randomly selected from each treatment group to measure the plant height and root length with a ruler. The average value was used as the indicator of spinach growth.

The harvested spinach samples were washed with distilled water three times. The shoots and roots of the spinach were separated and dried at $105{ }^{\circ} \mathrm{C}$ for $30 \mathrm{~min}$, dried to 
constant weight at $60{ }^{\circ} \mathrm{C}$, and then ground into powder. A sample of $0.25 \mathrm{~g}$ was placed in a crucible, to which $10 \mathrm{~mL}$ of $\mathrm{HNO}_{3}-\mathrm{HClO}_{4}(4: 1$, v/v) mixture solution was added. The mixture was heated to digest, and the $\mathrm{Cd}$ content in the plant tissue was analyzed.

\section{Detection and Statistical Analysis}

An atomic absorption spectrophotometer (GFA-7000A, Shimadzu Corporation, Shimadzu, Japan) was used to determine the $\mathrm{Cd}$ content in the soil and digested plant tissue solutions. Origin 8.0 software (OriginLab, Northampton, MA, USA) was used for statistical processing of all test data.

\section{RESULTS AND DISCUSSION}

\section{Effects of Different Biochar Treatments on Soil pH}

Soil $\mathrm{pH}$ is the main factor controlling the adsorption, desorption, and precipitation balance of heavy metals. Moreover, it determines the migration and transformation behavior of heavy metals in the soil. Therefore, the soil $\mathrm{pH}$ can notably influence the bioavailability of heavy metals in the soil and the extent of the stress caused by them on plant growth. The effects of the different biochar treatments on the soil $\mathrm{pH}$ are shown in Fig. 1. The $\mathrm{pH}$ of the soil treated with $\mathrm{HBC}$ and $\mathrm{MHBC}$ increased by 0.32 to 2.50 units compared with $\mathrm{CK}$. This result was consistent with the results of other studies. For example, Wu et al. (2020) reported that the addition of calcium-based magnetic biochar significantly increased the $\mathrm{pH}$ of rice rhizosphere and non-rhizosphere soil. The ash produced by the pyrolysis of biomass generates many inorganic salt ions, such as $\mathrm{Mg}^{2+}, \mathrm{Ca}^{2+}, \mathrm{Na}^{+}$, and $\mathrm{K}^{+}$, which mostly exist as metal oxides and carbonates. Adding them to the soil increases the soil $\mathrm{pH}$. The salt ions of the biochar can also lead to $\mathrm{H}^{+}$and $\mathrm{Al}^{3+}$ exchange on the surface of soil colloids, thereby increasing the soil $\mathrm{pH}$ (Yuan et al. 2010). In addition, when the biochar is alkaline, it can increase the soil $\mathrm{pH}$, to some extent decreasing the content of exchangeable $\mathrm{Cd}^{2+}$ and thereby decreasing the consequent damage to the growth processes of crops (Van Zwieten et al. 2010). The soil $\mathrm{pH}$ values for $300 \mathrm{HBC}, 600 \mathrm{HBC}, 300 \mathrm{MHBC}$, and $600 \mathrm{MHBC}$ at $1 \%$ increased by $0.32,1.43,0.92$, and 2.21 units, respectively, compared with $\mathrm{CK}$. When the biochar concentration was increased to $2 \%$, the soil $\mathrm{pH}$ values increased by $1.36,2.11,1.89$, and 2.50 units, respectively, in comparison with CK. This result suggests that the soil $\mathrm{pH}$ increased with increasing concentration of biochar. These results are consistent with the findings of Yang et al. (2016), who reported that the addition of corn stalk biochar significantly increased soil $\mathrm{pH}$, and the improvement caused by $5 \%$ corn stalk biochar treatment was greater than with the $1 \%$ treatments. This result may be because biochar is an alkaline material, and more alkaline ions carried by the biochar enter the soil with increasing addition of biochar, thereby leading to a greater soil $\mathrm{pH}$. Moreover, the capacities of the HBC and MHBC to increase soil $\mathrm{pH}$ increased with increasing pyrolysis temperature. At the same concentration, the biochar produced at higher pyrolysis temperature increased the soil $\mathrm{pH}$ to a greater extent. Compared with the $\mathrm{HBC}$, the soil $\mathrm{pH}$ increased by 0.39 to 0.78 units with the addition of $\mathrm{MHBC}$, and the soil $\mathrm{pH}$ was greatest with the $2 \% 600 \mathrm{MHBC}$ treatment. This result demonstrates that the additions of magnesium and biochar had a synergistic effect on soil $\mathrm{pH}$. The $\mathrm{Mg}^{2+}$ loaded on the biochar surface can adsorb negatively charged $\mathrm{OH}^{-}$and $\mathrm{CO}_{3}{ }^{2-}$. Consequently, the inorganic magnesium led to a relatively high biochar $\mathrm{pH}$, thereby increasing the soil $\mathrm{pH}$ to a greater extent (Lee $e t$ al. 2017). 


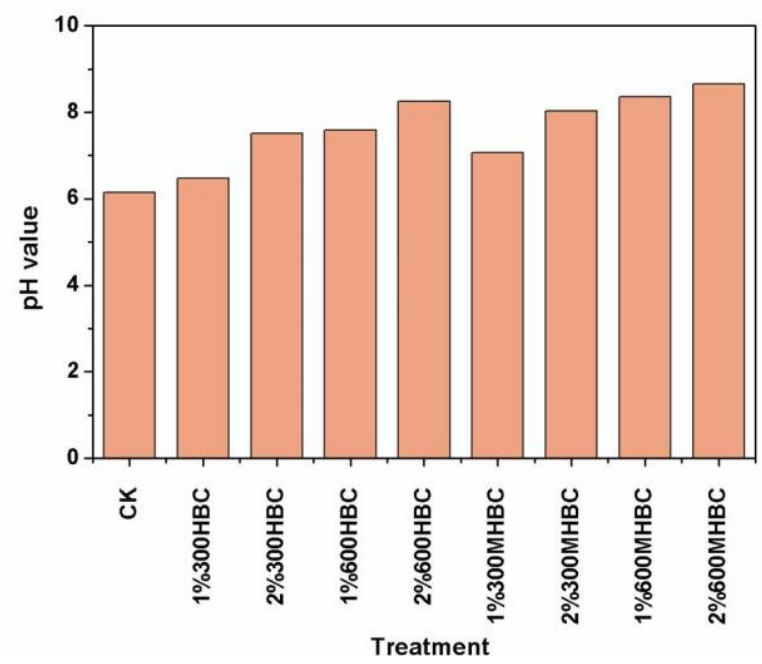

Fig. 1. Effects of different biochar treatments on soil pH

\section{Effects of Different Biochar Treatments on the Bioavailable Cd Content in the Soil}

The addition of $\mathrm{HBC}$ and $\mathrm{MHBC}$ significantly affected the bioavailable $\mathrm{Cd}^{2+}$ content in the soil. As shown in Fig. $2 \mathrm{a}$, in comparison with $\mathrm{CK}$, the content of bioavailable $\mathrm{Cd}^{2+}$ decreased by $5.6 \%, 6.4 \%, 26.2 \%$, and $45.0 \%$ with $1 \%$ concentration of $300 \mathrm{HBC}$, $600 \mathrm{HBC}, 300 \mathrm{MHBC}$, and $600 \mathrm{MHBC}$, respectively, and the content of bioavailable $\mathrm{Cd}^{2+}$ ranged from $4.35 \mathrm{mg} / \mathrm{kg}$ to $5.32 \mathrm{mg} / \mathrm{kg}$. The content of bioavailable $\mathrm{Cd}^{2+}$ in the soil decreased by $21.3 \%, 19.5 \%, 40.8 \%$, and $50.1 \%$ with $2 \% 300 \mathrm{HBC}, 600 \mathrm{HBC}, 300 \mathrm{MHBC}$, and $600 \mathrm{MHBC}$, respectively, and the bioavailable $\mathrm{Cd}^{2+}$ ranged from $2.16 \mathrm{mg} / \mathrm{kg}$ to 3.37 $\mathrm{mg} / \mathrm{kg}$. Therefore, the addition of biochar can effectively decrease the content of bioavailable $\mathrm{Cd}^{2+}$ in the soil, which decreased as the concentration of biochar increased from $1 \%$ to $2 \%$. This result is consistent with the results of Yang et al. (2016), who reported that the content of $\mathrm{CaCl}_{2}$-extractable $\mathrm{Cd}^{2+}$ in soil decreased as the concentration of biochar increased from $0 \%$ to $5 \%$. This result probably occurred because more active adsorption sites were provided for the soil with greater biochar concentrations, which increased the soil $\mathrm{pH}$ to a greater extent, thereby improving the fixation capacity of the soil for $\mathrm{Cd}^{2+}$. Moreover, as the biochar concentration increased, the desorption rate of the $\mathrm{Cd}^{2+}$, which was adsorbed by the soil surface, decreased (Abbas et al. 2017). However, Qayyum et al. (2019) demonstrated that the content of bioavailable $\mathrm{Cd}^{2+}$ significantly decreased and was effectively fixed in a soil contaminated by a relatively low $\mathrm{Cd}^{2+}$ level $(25 \mathrm{mg} / \mathrm{kg})$ as the concentration of cotton stalk biochar increased from $2 \%$ to $5 \%$. However, the results were contrary for soils with relatively greater $\mathrm{Cd}^{2+}$ contamination $(50 \mathrm{mg} / \mathrm{kg}$ and $100 \mathrm{mg} / \mathrm{kg})$. These results illustrate that the effect of biochar on the fixation of $\mathrm{Cd}^{2+}$ can also be affected by the contamination level of $\mathrm{Cd}$ in the soil. Furthermore, for the same concentration, the content of bioavailable $\mathrm{Cd}^{2+}$ in the soil decreased as the pyrolysis temperature increased, and the values were ranked as follows: $300 \mathrm{HBC}>600 \mathrm{HBC}>300 \mathrm{MHBC}>600 \mathrm{MHBC}$. Karimi et al. (2020) reported that a sludge biochar prepared at $600{ }^{\circ} \mathrm{C}$ effectively decreased the exchangeable form of $\mathrm{Pb}^{2+}$ and $\mathrm{Cd}^{2+}$ in the soil, and its effect was more significant than that of the biochar prepared at $300{ }^{\circ} \mathrm{C}$. This result further illustrates that the greater pyrolysis temperatures correspond to greater fixation capacity of the biochar for $\mathrm{Pb}^{2+}$ and $\mathrm{Cd}^{2+}$ in the soil. Studies have shown that biochar prepared via low-temperature pyrolysis 
$\left(<300{ }^{\circ} \mathrm{C}\right)$ mainly produces aliphatic alkylated oxygen, whereas biochars formed by hightemperature pyrolysis $\left(>300{ }^{\circ} \mathrm{C}\right.$ ) contain abundant aromatic structures ( $\mathrm{Li}$ et al. 2013). Therefore, a greater pyrolysis temperature contributes to the formation of aromatic functional groups on the surface of the biochar, such as $\mathrm{O}-\mathrm{H}, \mathrm{C}=\mathrm{C}$, and $\mathrm{C}=\mathrm{O}$. These structures can enhance the adsorption capacity of the biochar by strengthening hydrogen and dipole bonds (Chen et al. 2019). The abundant surface functional groups and aromatic structures of the biochar can also act as electron donors or receptors to adsorb $\mathrm{Cd}^{2+}$ by $\pi-\pi$ electron donor-receptor interactions (EDA), thereby decreasing the content of bioavailable $\mathrm{Cd}^{2+}$ in the soil. Compared with the HBC, the MHBC had a stronger inhibitory effect on the bioavailable $\mathrm{Cd}^{2+}$ content in the soil in a short period of time $(30 \mathrm{~d})$. The content of bioavailable $\mathrm{Cd}^{2+}$ after the MHBC treatment decreased by $26.2 \%$ to $50.1 \%$ compared with the $\mathrm{CK}$ treatment, which was a greater reduction than that of the HBC treatment $(5.6 \%$ to $21.3 \%$ ). This result demonstrates that the $\mathrm{Cd}^{2+}$ fixation capacity of the biochar in the soil was improved by the $\mathrm{Mg}$ loading, and the passivation effect of the $2 \% \mathrm{MHBC}$ prepared at $600{ }^{\circ} \mathrm{C}$ was the greatest. This result might be due to the magnesium loaded on the biochar surface after the pyrolysis process in preparing the MHBC. Magnesium hydroxide was precipitated due to the increased soil $\mathrm{pH}$, which promoted the co-precipitation of $\mathrm{Mg}^{2+}$ and $\mathrm{Cd}^{2+}$ in the soil solution (Ngambia et al. 2019; Li et al. 2020), thereby decreasing the content of bioavailable $\mathrm{Cd}^{2+}$ in the soil.
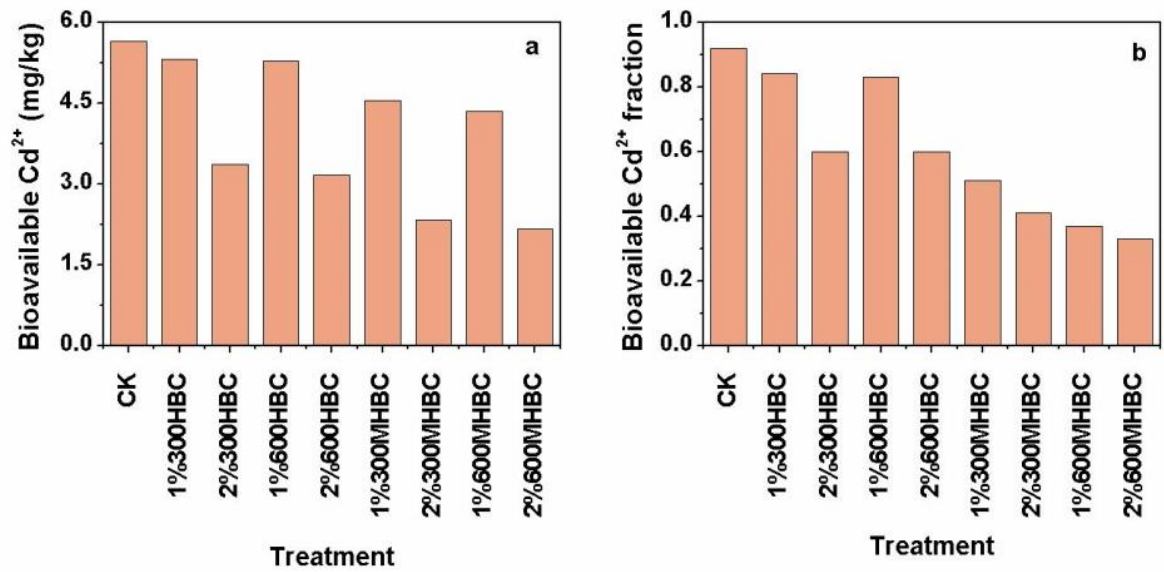

Fig. 2. Effects of different treatments on (a) bioavailable $\mathrm{Cd}^{2+}$ and (b) fraction of bioavailable $\mathrm{Cd}^{2+}$ to total $\mathrm{Cd}^{2+}$

The fraction of bioavailable $\mathrm{Cd}^{2+}$ to total $\mathrm{Cd}^{2+}$ under different biochar treatments are shown in Fig. 2b. The addition of HBC or MHBC decreased the fraction of bioavailable $\mathrm{Cd}^{2+}$ to total $\mathrm{Cd}^{2+}$ in the soil, and as the biochar concentration increased, the fraction of bioavailable $\mathrm{Cd}^{2+}$ tended to decrease. Compared with the $\mathrm{CK}$ treatment, the fractions of bioavailable $\mathrm{Cd}^{2+}$ treated with $1 \% 300 \mathrm{HBC}, 2 \% 300 \mathrm{HBC}, 1 \% 600 \mathrm{HBC}$, and $2 \% 600 \mathrm{HBC}$ decreased by $8.7 \%, 34.8 \%, 9.8 \%$, and $34.8 \%$, respectively. By contrast, the fractions of bioavailable $\mathrm{Cd}^{2+}$ in the soil treated with $1 \% 300 \mathrm{MHBC}, 2 \% 300 \mathrm{MHBC}, 1 \% 600 \mathrm{MHBC}$, and $2 \% 600 \mathrm{MHBC}$ decreased by $44.6 \%, 55.4 \%, 59.8 \%$, and $64.1 \%$, respectively. The fractions of bioavailable $\mathrm{Cd}^{2+}$ to total $\mathrm{Cd}^{2+}$ were ranked as $300 \mathrm{HBC}>600 \mathrm{HBC}>$ $300 \mathrm{MHBC}>600 \mathrm{MHBC}$ for the same concentration of HBC and MHBC, thus indicating that the fraction of bioavailable $\mathrm{Cd}^{2+}$ in the soil decreased as the pyrolysis temperature increased. 
To explore the mechanism of the effect of biochar addition on the content of bioavailable $\mathrm{Cd}^{2+}$ in the soil, the correlation between soil $\mathrm{pH}$ and fraction of bioavailable $\mathrm{Cd}^{2+}$ to total $\mathrm{Cd}^{2+}$ was analyzed. As shown in Fig. 3, this correlation was significant ( $\mathrm{p}<$ 0.01 ), which further demonstrates that the biochar immobilized $\mathrm{Cd}^{2+}$ in the soil mainly by increasing soil $\mathrm{pH}$ and weakening its bioavailability. Huang et al. (2020) reported that the proportion of bioavailable $\mathrm{Cd}^{2+}$ to total $\mathrm{Cd}^{2+}$ was $48.5 \%$ in an acidic soil and $5.0 \%$ in an alkaline soil. This result is consistent with the results of Ali et al. (2020), which suggested that the addition of biochar derived from apricot shells can decrease the bioavailability of $\mathrm{Cd}^{2+}$ in soil by increasing soil $\mathrm{pH}$ and ultimately decreasing crop uptake. Such results can be attributed to two reasons.

First, the addition of $\mathrm{HBC}$ and $\mathrm{MHBC}$ increased the soil $\mathrm{pH}$, and the consequent greater concentration of $\mathrm{OH}^{-}$in the soil led to the hydrolyzation of $\mathrm{Cd}^{2+}$, which precipitated to $\mathrm{Cd}(\mathrm{OH})_{2}$. The adsorption of $\mathrm{Cd}^{2+}$ was enhanced because the adsorption affinity of the soil for metal hydroxides was greater than that for free metal cations. Consequently, the bioavailability of $\mathrm{Cd}^{2+}$ was decreased (Yuan et al. 2010). Second, in addition to increasing the negative surface charge of clay minerals in the soil, greater soil $\mathrm{pH}$ also weakens the competitive adsorption of $\mathrm{H}^{+}$and $\mathrm{Cd}^{2+}$. Therefore, the adsorption capacity of negatively charged soil colloids for $\mathrm{Cd}^{2+}$ was promoted. Meanwhile, precipitation of compounds such as $\mathrm{Cd}(\mathrm{OH})_{2}, \mathrm{CdCO}_{3}$, and $\mathrm{Cd}_{3}\left(\mathrm{PO}_{4}\right)_{2}$ also occurred, which decreased the bioavailability of $\mathrm{Cd}^{2+}$. However, the fraction of bioavailable $\mathrm{Cd}^{2+}$ to total $\mathrm{Cd}^{2+}$ was not fully consistent with the variation trend of soil $\mathrm{pH}$. For instance, the $\mathrm{pH}$ of the soil treated with $1 \% 600 \mathrm{HBC}$ was 0.28 units larger than that of the soil treated with $2 \% 300 \mathrm{HBC}$, and the fraction of bioavailable $\mathrm{Cd}^{2+}$ in the former sample was $23 \%$ greater, which did not follow the negative correlation (Figs. 1 and 2b). This result indicates that the content of bioavailable $\mathrm{Cd}^{2+}$ in the soil was not completely determined by soil $\mathrm{pH}$, and it may be closely related to the adsorption and desorption processes of $\mathrm{HBC}$ and $\mathrm{MHBC}$ for $\mathrm{Cd}^{2+}$ in the soil.

The structure of the biochar determines if it can effectively adsorb $\mathrm{Cd}^{2+}$ in the soil through surface adsorption and pore filling, thereby fixating the $\mathrm{Cd}^{2+}$ and decreasing its bioavailability. As shown in scanning electron microscopy (SEM) analysis of HBC and MHBC (Chen et al. 2020), the pristine biochar and Mg-modified biochar had welldeveloped pore structures and high specific surface area, which exhibited a significant increase after loading $\mathrm{MgCl}_{2}$ on the surface of peanut shell biochar. The pristine biochar presented a relative smooth surface with lesser pores than $\mathrm{Mg}$-modified biochar, which can also explain the adsorption capacity of $\mathrm{MHBC}$ for $\mathrm{Cd}$ was better than $\mathrm{HBC}$ and thus posing a more significant effect on decreasing the bioavailability of $\mathrm{Cd}$ in soil. Moreover, according to the SEM analysis, the surface of $\mathrm{MHBC}$ was covered with irregular particles, which has been corroborated $\mathrm{MgO}$ and $\mathrm{Mg}(\mathrm{OH})_{2}$ crystal particle by Energy Dispersive Spectrometer (EDS) analysis in our previous study (Chen et al. 2020). This indicated that $\mathrm{Mg}$ was successfully deposited on the surface of biochar and may improve the adsorption capacity of biochar-soil system for $\mathrm{Cd}$ by ion exchange process to some extent. Fouriertransform infrared spectroscopy of $\mathrm{HBC}$ and $\mathrm{MHBC}$ suggests that their surfaces are rich in functional groups such as -OH corresponded to the peak of $3462 \mathrm{~cm}^{-1},-\mathrm{CH}_{3}\left(2944 \mathrm{~cm}^{-1}\right)$, carbonate $\left(833 \mathrm{~cm}^{-1}\right),-\mathrm{C}=\mathrm{O}\left(1633 \mathrm{~cm}^{-1}\right)$, and $\mathrm{C}=\mathrm{C}\left(1450 \mathrm{~cm}^{-1}\right)$, among which acidic oxygen-containing functional groups such as carboxyl can complex with $\mathrm{Cd}^{2+}$ in the soil, thereby decreasing its bioavailability (Chen et al. 2020). In addition, biochars are rich in organic matter, which can also promote the formation of stable complexes between heavy metals (such as $\mathrm{Cd}^{2+}$ ) and organic matter, thereby decreasing the $\mathrm{Cd}^{2+}$ bioavailability (Zia ur Rehman et al. 2017). In this study, the inherent properties of biochar were changed by 
$\mathrm{MgCl}_{2}$ modification, and the content of cation ions also increased. These transformation can account for the more significant reduction effect of MHBC on the bioavailability of Cd in soil.

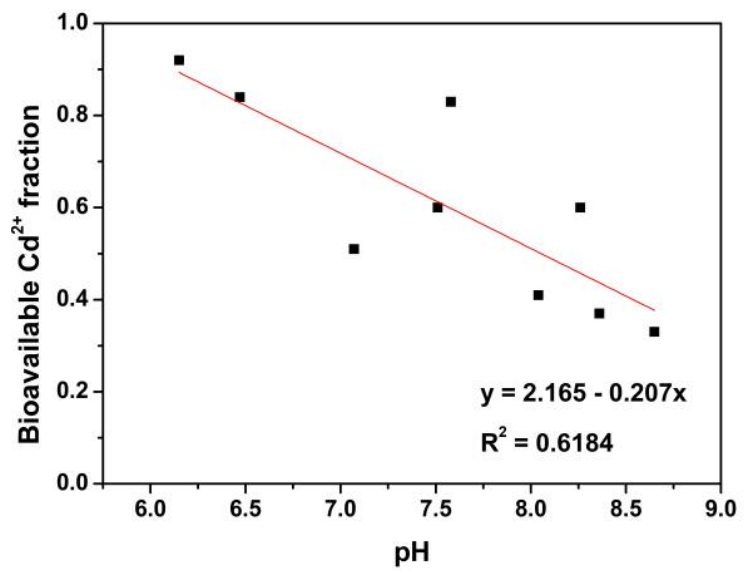

Fig. 3. Correlation between soil $\mathrm{pH}$ and fraction of bioavailable $\mathrm{Cd}^{2+}$ to total $\mathrm{Cd}^{2+}$ upon different treatments

\section{Effects of Different Treatments on the Biomass of Spinach}

The effects of the HBC and MHBC treatments on the growth of spinach shoots and roots are shown in Fig. 4. The addition of HBC and MHBC increased the shoot height by $37.2 \%$ to $80.1 \%$ compared with CK. This result can be attributed to the biochar's alkalinity, which was conducive to the deprotonation of hydroxyl, carboxyl, and other acidic functional groups in the soil. As the negative surface charge of the soil colloids and biochar increased, free heavy metal ions with positive charge were adsorbed to neutralize the surface charge, thus improving the adsorption capacity of the soil and, consequently, its $\mathrm{Cd}^{2+}$ amendment potential. Therefore, the addition of biochar could decrease the bioavailability of $\mathrm{Cd}^{2+}$ in the soil, thereby decreasing the toxic stress on spinach and increasing its yield. The shoot height of the spinach increased with increasing concentrations of HBC and MHBC. Compared with CK, the shoot heights of $1 \% 300 \mathrm{HBC}$, $2 \% 300 \mathrm{HBC}, 1 \% 600 \mathrm{HBC}$, and $2 \% 600 \mathrm{HBC}$ increased by $37.2 \%, 50.1 \%, 48.9 \%$, and $49.8 \%$, respectively. Moreover, the shoot heights of $1 \% 300 \mathrm{MHBC}, 2 \% 300 \mathrm{MHBC}$, $1 \% 600 \mathrm{MHBC}$, and $2 \% 600 \mathrm{MHBC}$ increased by $66.5 \%, 70.8 \%, 73.8 \%$, and $80.8 \%$, respectively. This result is contrary to the findings of Wu et al. (2020), whose results show that the effect of $1 \%$ magnetic calcium-based rice straw biochar on the growth of rice was stronger than that of $2 \%$ addition to an As polluted soil. This probably occurred because the negative charges on the surfaces of the soil colloids increased with increasing biochar concentration, which resulted in the repulsion of As anions in the soil. Therefore, the bioavailability of As was enhanced, and the bioavailable As was absorbed more easily by the plant, thereby inhibiting its growth. In contrast, Tao et al. (2019) reported results consistent with the present study. In their study, the $\mathrm{Cd}^{2+}$ stress in the soil was alleviated as the biochar concentration increased from $0 \%$ to $5 \%$, which significantly promoted the germination and growth of pakchoi. The differences between these results may be due to the different valence $\left(\mathrm{Cd}^{2+}\right.$, As anions) which determined the repulsion and adsorption behavior of heavy metal ions then influencing their bioavailability when the negative charges on the surfaces of the soil colloids increased after adding biochar. 


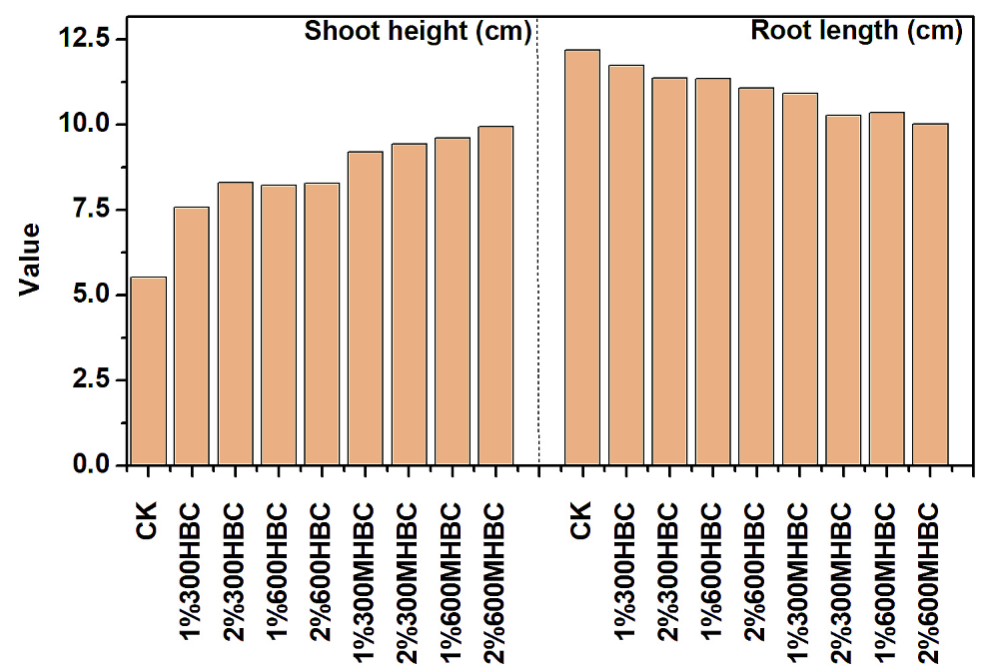

Fig. 4. Effects of different biochar treatments on spinach biomass
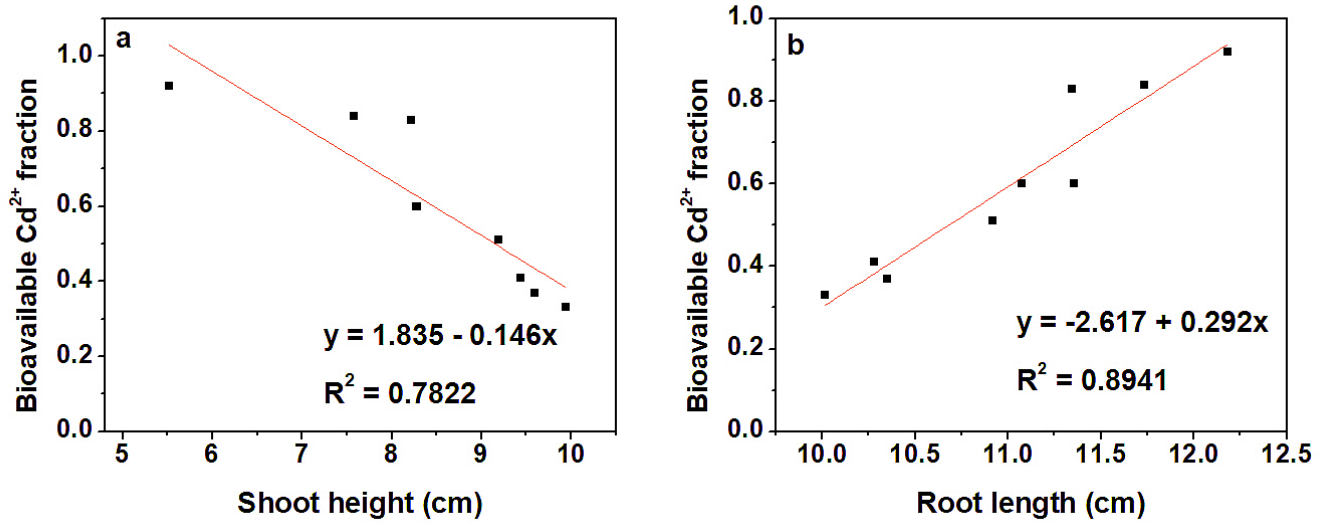

Fig. 5. Correlations between (a) shoot height and (b) root length of spinach and the fraction of bioavailable $\mathrm{Cd}^{2+}$ to total $\mathrm{Cd}^{2+}$

Therefore, the effect of biochar on plant growth in a heavy-metal-stressed soil depends on the characteristics of the biochar, plant species, and heavy metal properties, among which valence is the most important factor (Chen et al. 2015). The shoot heights of the spinach were ranked as follows: $300 \mathrm{HBC}<600 \mathrm{HBC}<300 \mathrm{MHBC}<600 \mathrm{MHBC}$. This result indicates that the shoot height of the spinach increased with increasing biochar pyrolysis temperature for the same concentration of HBC and MHBC. The shoot height related to the MHBC treatment was $9.20 \mathrm{~cm}$ to $9.95 \mathrm{~cm}$, which was significantly greater than those related to the HBC treatment $(7.58 \mathrm{~cm}$ to $8.29 \mathrm{~cm})$ and $\mathrm{CK}(5.52 \mathrm{~cm})$. These results indicate that the addition of $\mathrm{MHBC}$ was more conducive to the growth of the spinach overground part. This result was consistent with the results of Tao et al. (2019), in which the addition of Mg-modified biochar derived from Thalia dealbata had a more significantly effect than pristine biochar on the germination and growth of pakchoi. A possible reason for these results is that the biochar was rich in basic cations $\left(\mathrm{Mg}^{2+}\right)$, whose content increased by the modifying process. Abundant $\mathrm{Mg}^{2+}$ can promote the exchange of the $\mathrm{Mg}^{2+}$ loaded on the biochar surface with the $\mathrm{Cd}^{2+}$ in soil, thereby fixing $\mathrm{Cd}^{2+}$ on the 
biochar surface. In addition, $\mathrm{Mg}^{2+}$ can provide nutrients for the spinach, which promote its growth to some extent. Therefore, the shoot height increased with increasing biochar concentration and pyrolysis temperature, and MHBC had more significant effects on the increase of spinach shoot height. Then the shoot height increased the most in the $2 \% 600 \mathrm{MHBC}$ treatment compared with CK. This is consistent with the findings of Lu et al. (2014), who reported that the shoot biomass of Sedum plumbizincicola in 5\% bamboo biochar treatment was higher than $1 \%$ treatment and CK under Cd stress. On the one hand, this was related to the extractable $\mathrm{Cd}$ content which was lower in $5 \%$ biochar treatment. The heavy metal $\mathrm{Cd}$ has been reported that can decrease spinach biomass (Younis et al. 2016). Then the stress effect on plant growth was lesser in $5 \%$ biochar treatment. On the other hand, the total shoot nutrient element $\mathrm{N}$ content and the shoot $\mathrm{N}$ concentration in 5\% biochar treatment were significantly higher than that in $1 \%$ and CK. Therefore, different concentration of biochar can affect plant biomass by influencing its nutrient absorption capacity. Moreover, in this study, the $\mathrm{pH}$ value of biochar-soil system increased with the pyrolysis temperature of biochar increase. This may decrease the bioavailability of $\mathrm{Cd}$ and thus improving the plant biomass.

To further explore the effect of bioavailable $\mathrm{Cd}^{2+}$ on plant growth, the correlation between shoot height and fraction of bioavailable $\mathrm{Cd}^{2+}$ to total $\mathrm{Cd}^{2+}$ was analyzed. As shown in Fig. 5a, the spinach shoot height was negatively correlated with this fraction ( $p$ $<0.01$ ). This result may be attributed to the lower content of bioavailable $\mathrm{Cd}^{2+}$, which then caused a lower stress effect on the growth of the spinach. Therefore, the growth inhibition effect of the $\mathrm{Cd}^{2+}$ on the spinach was weak, and the shoots were able to grow relatively tall. In addition, Parra et al. (2017) observed that $\mathrm{Ca}^{2+}, \mathrm{Zn}^{2+}$, and $\mathrm{Fe}^{2+}$ were essential elements for plant growth and had similar physical properties to $\mathrm{Cd}^{2+}$, such as charge and ion radius. Other studies have also shown that $\mathrm{Cd}^{2+}$ competes with $\mathrm{Ca}^{2+}, \mathrm{Zn}^{2+}$, and $\mathrm{Fe}^{2+}$ for the same transport channel on the root surface when being absorbed into plant tissue (Tian et al. 2016). Therefore, the decreased content of $\mathrm{Cd}^{2+}$ decreased the competition between $\mathrm{Cd}^{2+}$ and essential elements for plant growth, which was conducive to nutrient uptake by the plant.

As shown in Fig. 4, the addition of $\mathrm{HBC}$ and MHBC decreased the length of the spinach root. Compared with $\mathrm{CK}$, the root length decreased by $3.7 \%$ to $17.8 \%$, and it decreased the most for the $2 \% 600 \mathrm{MHBC}$ treatment. As shown in Fig. 4, the root length decreased with increasing biochar concentration. For the $1 \% 300 \mathrm{HBC}, 2 \% 300 \mathrm{HBC}$, $1 \% 600 \mathrm{HBC}$, and $2 \% 600 \mathrm{HBC}$ treatments, the root lengths decreased by $3.7 \%, 6.8 \%, 6.8 \%$, and $9.1 \%$ compared to the $\mathrm{CK}$, respectively. For the $1 \% 300 \mathrm{MHBC}, 2 \% 300 \mathrm{MHBC}$, $1 \% 600 \mathrm{MHBC}$, and $2 \% 600 \mathrm{MHBC}$ treatments, the lengths decreased by $10.3 \%, 15.6 \%$, $15.0 \%$, and $17.8 \%$, respectively. A possible reason for these results is that the $2 \% \mathrm{HBC}$ and MHBC have more ions, and the increased soil conductivity led to a salt stress, which further inhibited the growth of spinach roots. The lengths of the spinach roots were ranked as follows: $300 \mathrm{HBC}>600 \mathrm{HBC}>300 \mathrm{MHBC}>600 \mathrm{MHBC}$, for the same concentrations of $\mathrm{HBC}$ and $\mathrm{MHBC}$. Therefore, the root length decreased with increasing pyrolysis temperature. In addition, compared with $\mathrm{HBC}$, MHBC had a stronger shortening effect on the root length. This result was consistent with the trend of fraction of bioavailable $\mathrm{Cd}^{2+}$ to total $\mathrm{Cd}^{2+}$ upon addition of biochar. As shown in Fig. 5b, there was a highly significant positive correlation between root length and fraction of bioavailable $\mathrm{Cd}^{2+}$ to total $\mathrm{Cd}^{2+}(\mathrm{p}$ $<0.01$ ). This probably occurred because the spinach roots were directly exposed to $\mathrm{Cd}^{2+}$ contaminated soil and were more sensitive to a $\mathrm{Cd}^{2+}$ contaminated environment. It was difficult for plant tissues to transport and absorb $\mathrm{Cd}^{2+}$ ions due to the decrease of 
bioavailable $\mathrm{Cd}^{2+}$ in the soil. Therefore, the spinach shoot contained less $\mathrm{Cd}^{2+}$, which accumulated more in the spinach root, thereby inhibiting its growth.

\section{Effects of Different Biochar Treatments on the Cd Content of Spinach}

The $\mathrm{Cd}^{2+}$ contents of the spinach shoots and roots treated with different biochars are shown in Fig. 6. Both treatments decreased the accumulation of $\mathrm{Cd}^{2+}$ in the shoots and roots. Compared with $\mathrm{CK}$, the $\mathrm{Cd}^{2+}$ content upon $\mathrm{HBC}$ and $\mathrm{MHBC}$ treatment decreased by $7.0 \%$ to $46.8 \%$ in the shoots and $7.3 \%$ to $52.7 \%$ in the roots. This result is likely due to the low molecular organic acid being the most active substance in the root exudates, among which oxalic acid was the main component (Muratova et al. 2009). Root exudates decrease soil $\mathrm{pH}$ and provide ligands for metal complexation reactions, thereby increasing the concentration of bioavailable $\mathrm{Cd}^{2+}$ in the soil. However, the addition of alkaline biochar neutralized organic acids in the plant root exudates, thereby fixing $\mathrm{Cd}^{2+}$ and decreasing its absorption by the plant. The biochar addition had a relatively mild effect on the decrease of $\mathrm{Cd}^{2+}$ content in the spinach shoots compared with the roots, which suggests that the spinach roots functioned as a barrier to $\mathrm{Cd}^{2+}$ absorption and were the main channel for $\mathrm{Cd}^{2+}$ to be transported to the aboveground parts of the plant.

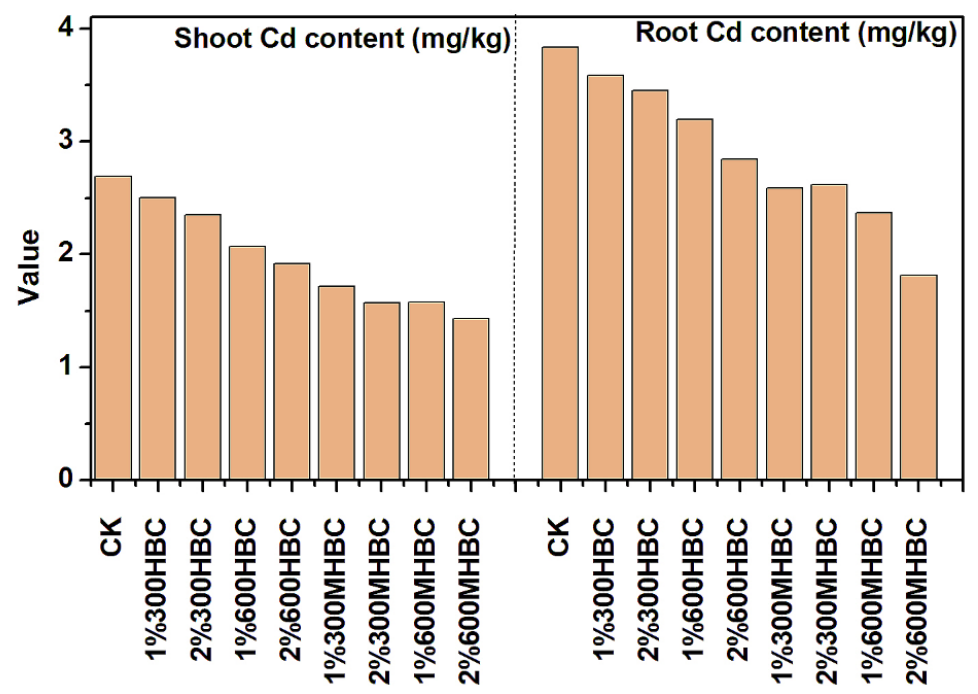

Fig. 6. Effects of different biochar treatments on the $\mathrm{Cd}^{2+}$ content in spinach

The concentrations of HBC and MHBC had a relatively low effect on the $\mathrm{Cd}^{2+}$ content of spinach shoots. The accumulation of $\mathrm{Cd}^{2+}$ in the spinach shoot decreased as the biochar concentration increased. The $\mathrm{Cd}^{2+}$ content in the shoots decreased by $6 \%$ upon treatment with $2 \% 300 \mathrm{HBC}$, compared with that of $1 \% 300 \mathrm{HBC}$, and it decreased by $7.2 \%$ with $2 \% 600 \mathrm{HBC}$, compared with that of $1 \% 600 \mathrm{HBC}$. The $\mathrm{Cd}^{2+}$ content upon $2 \% 300 \mathrm{MHBC}$ treatment was $8.7 \%$ less than that of the $1 \% 300 \mathrm{MHBC}$ treatment, and it was $9.5 \%$ less for $2 \% 600 \mathrm{MHBC}$ compared with that of $1 \% 600 \mathrm{MHBC}$. The accumulation of $\mathrm{Cd}^{2+}$ in the spinach shoot was the lowest $(1.43 \mathrm{mg} / \mathrm{kg})$ for the treatment of $2 \% 600 \mathrm{MHBC}$. The accumulation of $\mathrm{Cd}^{2+}$ in the spinach root decreased with increasing biochar concentration. Compared with $\mathrm{CK}$, the greatest reduction occurred for the $2 \% 600 \mathrm{MHBC}$ group, at $52.7 \%$. The accumulation of $\mathrm{Cd}^{2+}$ in the spinach shoots and roots decreased with increasing biochar concentration, which suggests that the addition of $\mathrm{HBC}$ and MHBC 
inhibited the absorption of $\mathrm{Cd}^{2+}$, and the increase of biochar concentration improved the inhibition of $\mathrm{Cd}^{2+}$ absorption. In addition, the shoot height increased with increasing biochar concentration, which had a certain dilution effect on the $\mathrm{Cd}^{2+}$ in the spinach shoot. The inhibition effects of biochar on the absorption of $\mathrm{Cd}^{2+}$ in both shoots and roots of the spinach were as follows: $300 \mathrm{HBC}<600 \mathrm{HBC}<300 \mathrm{MHBC}<600 \mathrm{MHBC}$. This result indicates that the inhibition of the $\mathrm{Cd}^{2+}$ adsorption increased with increasing biochar pyrolysis temperature. This result probably occurred because higher pyrolysis temperatures resulted in higher losses of fatty matter, volatile matter, and water, thereby forming a welldeveloped pore structure on the biochar surface (Zhang et al. 2013), which effectively promotes surface adsorption and pore filling for $\mathrm{Cd}^{2+}$ (Chen et al. 2019). Consequently, the bioavailability and mobility of $\mathrm{Cd}^{2+}$ in the soil decreased, and its absorption was inhibited. Compared with the $\mathrm{HBC}$, the inhibition effect of $\mathrm{MHBC}$ on the absorption of $\mathrm{Cd}^{2+}$ was greater. The accumulations of $\mathrm{Cd}^{2+}$ in the shoots and roots of spinach with MHBC decreased by $23.7 \%$ to $33.2 \%$ and $24.1 \%$ to $52.1 \%$, respectively, compared with the HBC at the same pyrolysis temperature and concentration. This result indicates that the magnesium modification had a synergistic effect on pristine biochar in inhibiting the absorption of $\mathrm{Cd}^{2+}$ by the spinach.

As shown in Fig. 6 and Fig. 2b, the variations of the $\mathrm{Cd}^{2+}$ content absorbed by the shoots and roots of the spinach for different treatments were mostly consistent with the fraction of bioavailable $\mathrm{Cd}^{2+}$ to total $\mathrm{Cd}^{2+}$. To further explore the influence of bioavailable $\mathrm{Cd}^{2+}$ in soil on the accumulation of $\mathrm{Cd}^{2+}$ in plants, the correlations between the accumulations of $\mathrm{Cd}^{2+}$ in the shoots (Fig. 7a) and roots (Fig. 7b) of the spinach and the fractions of bioavailable $\mathrm{Cd}^{2+}$ to total $\mathrm{Cd}^{2+}$ were analyzed.
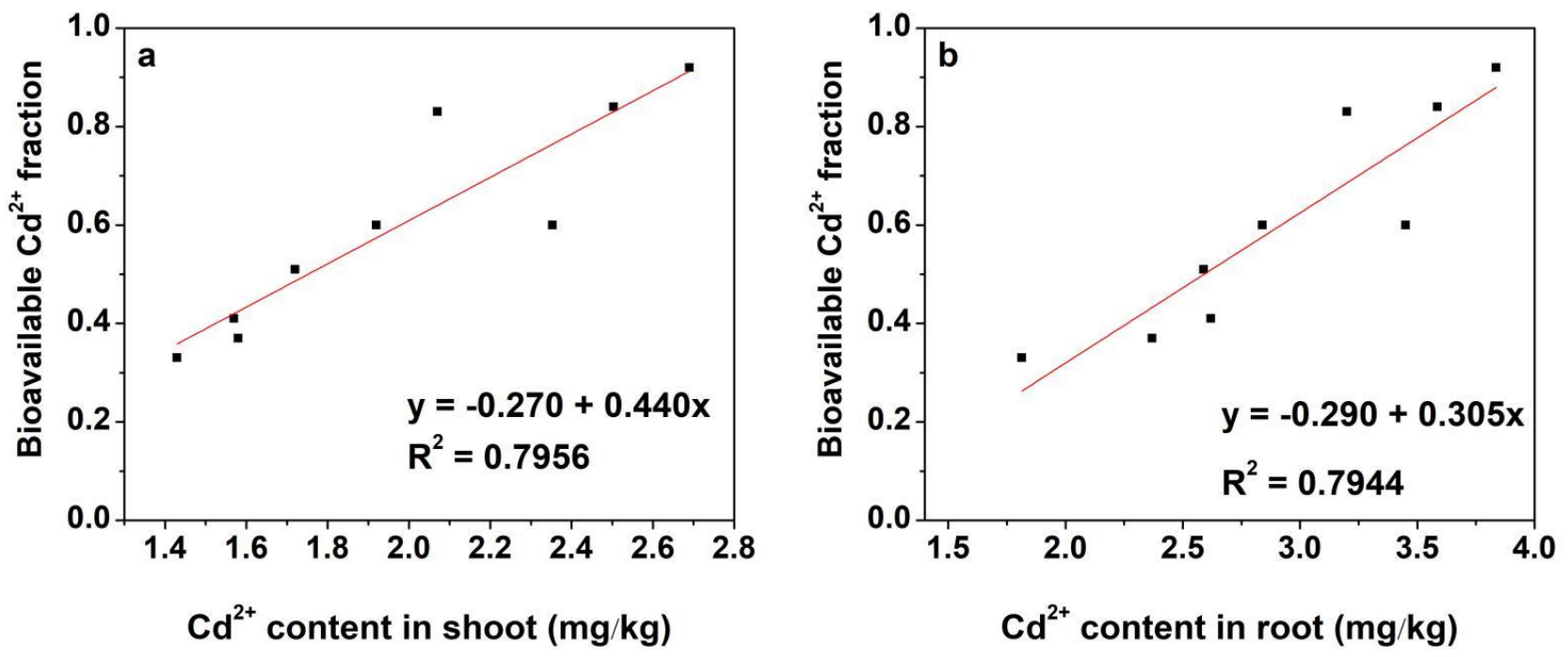

Fig. 7. Correlation between accumulation of $\mathrm{Cd}^{2+}$ in spinach (a) shoots and (b) roots and the fraction of bioavailable $\mathrm{Cd}^{2+}$ to total $\mathrm{Cd}^{2+}$

As shown in Fig. 7, the contents of $\mathrm{Cd}^{2+}$ in both shoots and roots of the spinach were positively correlated with the fraction of bioavailable $\mathrm{Cd}^{2+}(\mathrm{p}<0.01)$. This result indicates that the $\mathrm{Cd}^{2+}$ content in the spinach was mainly affected by the content of bioavailable $\mathrm{Cd}^{2+}$ in the soil. This result is consistent with the results of Huang et al. (2020), in which the $\mathrm{Cd}^{2+}$ absorption by plants was mainly related to bioavailable $\mathrm{Cd}^{2+}$, instead of 
total $\mathrm{Cd}^{2+}$ content in the soil. The addition of HBC and MHBC decreased the content of bioavailable $\mathrm{Cd}^{2+}$ in the soil, thus decreasing its uptake by plants. The accumulation of $\mathrm{Cd}^{2+}$ in the spinach was greater in the roots than in the shoots, and the average $\mathrm{Cd}^{2+}$ content in the roots was $32.2 \%$ greater than that in the shoots. Thus, the distribution of $\mathrm{Cd}^{2+}$ in the spinach presented an obvious root accumulation effect.

\section{CONCLUSIONS}

1. The addition of peanut shell biochar (HBC) and Mg-modified peanut shell biochar (MHBC) effectively increased the soil $\mathrm{pH}$ with increasing biochar concentration and pyrolysis temperature. The effect of $\mathrm{MHBC}$ on $\mathrm{pH}$ increase was greater than that of HBC.

2. Both HBC and MHBC effectively decreased the content of bioavailable $\mathrm{Cd}^{2+}$ in the soil, thereby decreasing the amount of $\mathrm{Cd}^{2+}$ absorbed by the shoots and roots of the spinach. The bioavailable $\mathrm{Cd}^{2+}$ content in the soil and the $\mathrm{Cd}^{2+}$ absorbed by the spinach decreased with increasing biochar concentration and pyrolysis temperature. The MHBC had the greater effect on the decrease of bioavailable $\mathrm{Cd}^{2+}$, indicating that the MHBC can better decrease the bioavailability of heavy metals.

3. The addition of the HBC and MHBC significantly increased the shoot height and decreased the root length of the spinach, and the effects were greater as the biochar concentration and pyrolysis temperature increased. The effects of the MHBC on plant height and root length were greater than those of the HBC.

\section{ACKNOWLEDGMENTS}

This study was supported by the National Natural Science Foundation of China (Grant Nos. 41501542 and 41471389).

\section{REFERENCES CITED}

Abbas, T., Rizwan, M., Ali, S., Zia-ur-Rehman, M., Qayyum, M. F., Abbas, F., Hannan, F., Rinklebe, J., and Ok, Y. S. (2017). "Effect of biochar on cadmium bioavailability and uptake in wheat (Triticum aestivum L.) grown in a soil with aged contamination," Ecotoxicology and Environmental Safety 140, 37-47. DOI: 10.1016/j.ecoenv.2017.02.028

Ali, A., Shaheen, S. M., Guo, D., Li, Y., Xiao, R., Wahid, F., Azeem, M., Sohail, K., Zhang, T., Rinklebe, J., et al. (2020). "Apricot shell- and apple tree-derived biochar affect the fractionation and bioavailability of $\mathrm{Zn}$ and $\mathrm{Cd}$ as well as the microbial activity in smelter contaminated soil," Environmental Pollution 264. DOI: 10.1016/j.envpol.2020.114773

Ashrafi, M., Mohamad, S., Yusoff, I., and Hamid, F. S. (2015). "Immobilization of Pb, $\mathrm{Cd}$, and $\mathrm{Zn}$ in a contaminated soil using eggshell and banana stem amendments: Metal leachability and a sequential extraction study," Environmental Science and Pollution Research 22, 223-230. DOI: 10.1007/s11356-014-3299-4

Awad, M., Moustafa-Farag, M., Wei, L., Huang, Q., and Liu, Z. Z. (2020). "Effect of 
garden waste biochar on the bioavailability of heavy metals and growth of Brassica juncea (L.) in a multi-contaminated soil," Arabian Journal of Geosciences 13, 225231. DOI: $10.1007 / \mathrm{s} 12517-020-05376-\mathrm{w}$

Bashir, S., Hussain, Q., Zhu, J., Fu, Q. L., Houben, D., and Hu, H. Q. (2020). 'Efficiency of $\mathrm{KOH}$-modified rice straw-derived biochar for reducing cadmium mobility, bioaccessibility and bioavailability risk index in red soil," Pedosphere 30, 874-882. DOI: 10.1016/S1002-0160(20)60043-1

Cairns, S., Robertson, I., Sigmund, G., and Street-Perrott, A. (2020). "The removal of lead, copper, zinc and cadmium from aqueous solution by biochar and amended biochars," Environmental Science and Pollution Research 27, 21702-21715. DOI: 10.1007/s11356-020-08706-3

Chen, T., Zhou, Z. Y., Xu, S., Wang, H. T., and Lu, W. J. (2015). “Adsorption behavior comparison of trivalent and hexavalent chromium on biochar derived from municipal sludge," Bioresource Technology 190, 388-394. DOI: 10.1016/j.biortech.2015.04.115

Chen, Y., Jiang, Z., Wu, D., Wang, H., Li, J., Bi, M., and Zhang, Y. (2019). "Development of a novel bio-organic fertilizer for the removal of atrazine in soil," Journal of Environmental Management 233, 553-560. DOI: 10.1016/j.jenvman.2018.12.086

Chen, Y., Shan, R., and Sun, X. (2020). "Adsorption of cadmium by magnesiummodified biochar at different pyrolysis temperatures," BioResources 15(1), 767-786. DOI: 10.15376/biores.15.1.767-786

Dai, Y., Liu, R., Zhou, Y., Li, N., Hou, L., Ma, Q., and Gao, B. (2020). "Fire Phoenix facilitates phytoremediation of PAH-Cd co-contaminated soil through promotion of beneficial rhizosphere bacterial communities," Environment International 136. DOI: 10.1016/j.envint.2019.105421

Fan, Z. X., Zhang, Q., Li, M., Niu, D. Y., Sang, W. J., and Verpoort, F. (2018). "Investigating the sorption behavior of cadmium from aqueous solution by potassium permanganate-modified biochar: Quantify mechanism and evaluate the modification method," Environmental Science and Pollution Research 25, 8330-8339. DOI: 10.1007/s11356-017-1145-1

Farrag, K., Senesi, N., Soler Rovira, P., and Brunetti, G. (2012). "Effects of selected soil properties on phytoremediation applicability for heavy-metal-contaminated soils in the Apulia region, southern Italy," Environmental Monitoring and Assessment 184(11), 6593-6606. DOI: 10.1007/s10661-011-2444-5

Guo, B., Liu, C., Liang, Y., Li, N., and Fu, Q. (2019). "Salicylic acid signals plant defence against cadmium toxicity," International Journal of Molecular Sciences 20(12). DOI: 10.3390/ijms20122960

Huang, R., Dong, M., Mao, P., Zhuang, P., Paz-Ferreiro, J., Li, Y., Li, Y., Hu, X., Netherway, P., and Li, Z. (2020). "Evaluation of phytoremediation potential of five Cd (hyper)accumulators in two Cd contaminated soils," Science of the Total Environment 721. DOI: 10.1016/j.scitotenv.2020.137581

Huang, Y. Y., He, C. T., Shen, C., Guo, J. J., Mubeen, S., Yuan, J. G., and Yang, Z. Y. (2017). "Toxicity of cadmium and its health risks from leafy vegetable consumption," Food \& Function 8, 1373-1401. DOI: 10.1039/c6fo01580h

Jin, J., Kang, M., Sun, K., Pan, Z., Wu, F., and Xing, B. (2016). "Properties of biocharamended soils and their sorption of imidacloprid, isoproturon, and atrazine," Science of The Total Environment 550, 504-513. DOI: 10.1016/j.scitotenv.2016.01.117

Karimi, F., Rahimi, G., Kolahchi, Z., and Nezhad, A. K. J. (2020). "Using industrial 
sewage sludge-derived biochar to immobilize selected heavy metals in a contaminated calcareous soil," Waste and Biomass Valorization 11, 2825-2836. DOI: 10.1007/s12649-018-00563-Z

Laspina, N. V., Groppa, M. D., Tomaro, M. L., and Benavides, M. P. (2005). "Nitric oxide protects sunflower leaves against Cd-induced oxidative stress," Plant Science 169(2), 323-330. DOI: 10.1016/j.plantsci.2005.02.007

Lee, Y.-E., Jo, J.-H., Kim, I.-T., and Yoo, Y.-S. (2017). "Chemical characteristics and $\mathrm{NaCl}$ component behavior of biochar derived from the salty food waste by water flushing," Energies 10(10). DOI: 10.3390/en10101555

Li, A. Y., Deng, H., Jiang, Y. H., Ye, C. H., Yu, B. G., Zhou, X. L., and Ma, A. Y. (2020a). "Superefficient removal of heavy metals from wastewater by mg-loaded biochars: Adsorption characteristics and removal mechanisms," Langmuir: the ACS Journal of Surfaces and Colloids 36, 9160-9174. DOI: 10.1021/acs.langmuir.0c01454

Li, W., Liu, B., Wang, Z., Wang, K., Lan, Y., and Zhou, L. (2020b). “Efficient activation of peroxydisulfate (PDS) by rice straw biochar modified by copper oxide (RSBC$\mathrm{CuO}$ ) for the degradation of phenacetin (PNT)," Chemical Engineering Journal 395. DOI: 10.1016/j.cej.2020.125094

Li, X., Shen, Q., Zhang, D., Mei, X., Ran, W., Xu, Y., and Yu, G. (2013). "Functional groups determine biochar properties (pH and EC) as studied by two-dimensional ${ }^{13} \mathrm{C}$ NMR correlation spectroscopy," PLoS One 8(6). DOI: 10.1371/journal.pone.0065949

Lu, K. P., Yang, X., Shen, J. J., Robinson, B., Huang, H. G., Liu, D., Bolan, N., Pei, J. C., and Wang, H. L. (2014). "Effect of bamboo and rice straw biochars on the bioavailability of $\mathrm{Cd}, \mathrm{Cu}, \mathrm{Pb}$ and $\mathrm{Zn}$ to Sedum plumbizincicola," Agriculture, Ecosystems and Environment 191, 124-132. DOI: 10.1016/j.agee.2014.04.010

Micháleková-Richveisová, B., Frišták, V., Pipíška, M., Duriška, L., Moreno-Jimenez, E., and Soja, G. (2017). "Iron-impregnated biochars as effective phosphate sorption materials," Environmental Science and Pollution Research 24, 463-475. DOI: 10.1007/s11356-016-7820-9

Muratova, A., Golubev, S., Wittenmayer, L., Dmitrieva, T., Bondarenkova, A., Hirche, F., Merbach, W., and Turkovskaya, O. (2009). "Effect of the polycyclic aromatic hydrocarbon phenanthrene on root exudation of Sorghum bicolor (L.) Moench," Environmental and Experimental Botany 66(3), 514-521. DOI:

10.1016/j.envexpbot.2009.03.001

Ngambia, A., Ifthikar, J., Shahib, L. L., Jawad, A., Shahzad, A., Zhao, M. M., Wang, J., Chen, Z. L., and Chen, Z. Q. (2019). "Adsorptive purification of heavy metal contaminated wastewater with sewage sludge derived carbon-supported $\mathrm{Mg}$ (II) composite," Science of the Total Environment 691, 306-321. DOI: 10.1016/j.scitotenv.2019.07.003

Parra, A., Zornoza, R., Conesa, E., Faz, A., and Gómez-López, M. D. (2017). "Nutritional status and its interaction with soil properties and trace elements in six Mediterranean shrub species grown in reclaimed pyritic tailings," Ecological Engineering 109, 25-34. DOI: 10.1016/j.ecoleng.2017.08.027

Qayyum, M. F., Rehman, R. A., Liaqat, S., Ikram, M., Ali, S., Rizwan, M., Zia ur Rehman, M., Zafar-ul-Hye, M., and Hussain, Q. (2019). "Cadmium immobilization in the soil and accumulation by spinach (Spinacia oleracea) depend on biochar types under controlled and field conditions," Arabian Journal of Geosciences 12. DOI: 10.1007/s12517-019-4681-9

Shan, R., Chen, Y., Meng, L., Li, H., Zhao, Z., Gao, M., and Sun X. (2020). "Rapid 
prediction of atrazine sorption in soil using visible near-infrared spectroscopy," Spectrochimica Acta Part A: Molecular and Biomolecular Spectroscopy 224. DOI: 10.1016/j.saa.2019.117455

Shang, M.-r., Liu, Y.-g., Liu, S.-b., Zeng, G.-m., Tan, X.-f., Jiang, L.-h., Huang, X.-X., Ding, Y., Guo, Y.-m., and Wang, S.-f. (2016). "A novel graphene oxide coated biochar composite: Synthesis, characterization and application for $\mathrm{Cr}$ (VI) removal," RSC Advances 6(88), 85202-85212. DOI: 10.1039/C6RA07151A

Sidhu, G. P. S., Bali, A. S., Singh, H. P., Batich, D. R., Kohli, R. K. (2020). "Insights into the tolerance and phytoremediation potential of Coronopus didymus L.(Sm) grown under zinc stress," Chemosphere 244, 125350. DOI:

10.1016/j.chemosphere.2019.125350

Sun, X., Shan, R., Li, X., Pan, J., Liu, X., Deng, R., and Song, J. (2017).

"Characterization of 60 types of Chinese biomass waste and resultant biochars in terms of their candidacy for soil application," Global Change Biology Bioenergy 9(9), 1423-1435. DOI: $10.1111 / \mathrm{gcbb} .12435$

Tao, Q., Li, B., Li, Q., Han, X., Jiang, Y., Jupa, R., Wang, C., and Li, T. (2019). "Simultaneous remediation of sediments contaminated with sulfamethoxazole and cadmium using magnesium-modified biochar derived from Thalia dealbata," Science of the Total Environment 659, 1448-1456. DOI: 10.1016/j.scitotenv.2018.12.361

Tian, S., Xie, R., Wang, H., Hu, Y., Ge, J., Liao, X., Gao, X., Brown, P., Lin, X., and Lu, L. (2016). "Calcium deficiency triggers phloem remobilization of cadmium in a hyperaccumulating species," Plant Physiology 172, 2300-2313. DOI: 10.1104/pp.16.01348

Van Zwieten, L., Kimber, S., Morris, S., Chan, K. Y., Downie, A., Rust, J., Joseph, S., and Cowie, A. (2010). "Effects of biochar from slow pyrolysis of papermill waste on agronomic performance and soil fertility," Plant and Soil 327, 235-246. DOI: 10.1007/s11104-009-0050-X

Wang, L., Cui, X., Cheng, H., Chen, F., Wang, J., Zhao, X., Lin, C., and Pu, X. (2015). "A review of soil cadmium contamination in China including a health risk assessment," Environmental Science and Pollution Research 22, 16441-16452. DOI: 10.1007/s11356-015-5273-1

Wang, Y., Zhang, K., Lu, L., Xiao, X., and Chen, B. (2020). "Novel insights into effects of silicon-rich biochar (Sichar) amendment on cadmium uptake, translocation and accumulation in rice plants," Environmental Pollution 265. DOI: 10.1016/j.envpol.2020.114772

Wu, J., Li, Z., Wang, L., Liu, X., Tang, C., and Xu, J. (2020). “A novel calcium-based magnetic biochar reduces the accumulation of As in grains of rice (Oryza sativa L.) in As-contaminated paddy soils," Journal of Hazardous Materials 394. DOI: 10.1016/j.jhazmat.2020.122507

Yang, X., Liu, J., McGrouther, K., Huang, H., Lu, K., Guo, X., He, L., Lin, X., Che, L., Ye, Z., et al. (2016). "Effect of biochar on the extractability of heavy metals (Cd, Cu, $\mathrm{Pb}$, and $\mathrm{Zn}$ ) and enzyme activity in soil," Environmental Science and Pollution Research 23, 974-984. DOI: 10.1007/s11356-015-4233-0

Younis, U., Malik, S. A., Rizwan, M., Qayyum, M. F., Ok, Y. S., Shah, M. H. R., Rehman, R. A., and Ahmad, N. (2016). "Biochar enhances the cadmium tolerance in spinach (Spinacia oleracea) through modification of Cd uptake and physiological and biochemical attributes," Environmental Science and Pollution Research 23, 21385 21394. DOI: 10.1007/s11356-016-7344-3 
Yuan, J., and Xu, R. K. (2010). "Effects of rice-hull-based biochar regulating acidity of red soil and yellow brown soil," Journal of Ecology and Rural Environment 26(5), 472-476. DOI: 10.1080/00949651003724790

Zhang, P., Sun, H., Yu, L., and Sun, T. (2013). “Adsorption and catalytic hydrolysis of carbaryl and atrazine on pig manure-derived biochars: Impact of structural properties of biochars," Journal of Hazardous Materials 244-245, 217-224. DOI: 10.1016/j.jhazmat.2012.11.046

Zhang, S. Z., Quan, L. T., Zhu, Y. P., Yan, J., He, X. M., Zhang, J., Xu, X. M., Hu, Z. B., Hu, F., Chen, Y. H., Shen, Z. G., and Xia, Y. (2020). "Differential effects of three amendments on the immobilisation of cadmium and lead for Triticum aestivum grown on polluted soil," Environmental Science and Pollution Research DOI: 10.1007/s11356-020-10079-6

Zia ur Rehman, M., Khalid, H., Akmal, F., Ali, S., Rizwan, M., Qayyum, M. F., Iqbal, M, Khalid, M. U., and Azhar, M. (2017). "Effect of limestone, lignite and biochar applied alone and combined on cadmium uptake in wheat and rice under rotation in an effluent irrigated field," Environmental Pollution 227, 560-568. DOI:

10.1016/j.envpol.2017.05.003

Article submitted: July 16, 2020; Peer review completed: Aug. 29, 2020; Revised version received and accepted: Sept. 2, 2020; Published: September 4, 2020.

DOI: 10.15376/biores.15.4.8008-8025 